\title{
Apoptosis in cancer: from pathogenesis to treatment
}

\author{
Rebecca SY Wong
}

\begin{abstract}
Apoptosis is an ordered and orchestrated cellular process that occurs in physiological and pathological conditions. It is also one of the most studied topics among cell biologists. An understanding of the underlying mechanism of apoptosis is important as it plays a pivotal role in the pathogenesis of many diseases. In some, the problem is due to too much apoptosis, such as in the case of degenerative diseases while in others, too little apoptosis is the culprit. Cancer is one of the scenarios where too little apoptosis occurs, resulting in malignant cells that will not die. The mechanism of apoptosis is complex and involves many pathways. Defects can occur at any point along these pathways, leading to malignant transformation of the affected cells, tumour metastasis and resistance to anticancer drugs. Despite being the cause of problem, apoptosis plays an important role in the treatment of cancer as it is a popular target of many treatment strategies. The abundance of literature suggests that targeting apoptosis in cancer is feasible. However, many troubling questions arise with the use of new drugs or treatment strategies that are designed to enhance apoptosis and critical tests must be passed before they can be used safely in human subjects.
\end{abstract}

Keywords: Apoptosis, defective apoptotic pathways, carcinogenesis, treatment target

\section{Introduction}

Cell death, particularly apoptosis, is probably one of the most widely-studied subjects among cell biologists. Understanding apoptosis in disease conditions is very important as it not only gives insights into the pathogenesis of a disease but may also leaves clues on how the disease can be treated. In cancer, there is a loss of balance between cell division and cell death and cells that should have died did not receive the signals to do so. The problem can arise in any one step along the way of apoptosis. One example is the downregulation of p53, a tumour suppressor gene, which results in reduced apoptosis and enhanced tumour growth and development [1] and inactivation of $\mathrm{p} 53$, regardless of the mechanism, has been linked to many human cancers [2-4]. However, being a double-edged sword, apoptosis can be cause of the problem as well as the solution, as many have now ventured into the quest of new drugs targeting various aspects of apoptosis [5,6]. Hence,

\footnotetext{
Correspondence: rebecca_wong@imu.edu.my
}

Division of Human Biology, School of Medical and Health Sciences, International Medical University. No. 126, Jalan Jalil Perkasa 19, Bukit Jalil 57000 Kuala Lumpur, Malaysia apoptosis plays an important role in both carcinogenesis and cancer treatment. This article gives a comprehensive review of apoptosis, its mechanisms, how defects along the apoptotic pathway contribute to carcinogenesis and how apoptosis can be used as a vehicle of targeted treatment in cancer.

\section{Apoptosis}

The term "apoptosis" is derived from the Greek words " $\alpha \pi \sigma^{\prime \prime}$ and " $\pi \tau \omega \sigma \iota \zeta$ " meaning "dropping off" and refers to the falling of leaves from trees in autumn. It is used, in contrast to necrosis, to describe the situation in which a cell actively pursues a course toward death upon receiving certain stimuli [7]. Ever since apoptosis was described by Kerr et al in the 1970's, it remains one of the most investigated processes in biologic research [8]. Being a highly selective process, apoptosis is important in both physiological and pathological conditions $[9,10]$. These conditions are summarised in Table 1.

\subsection{Morphological changes in apoptosis}

Morphological alterations of apoptotic cell death that concern both the nucleus and the cytoplasm are 


\section{Table 1 Conditions involving apoptosis}

Physiological conditions
Programmed cell destruction in embryonic development for the
purpose of sculpting of tissue
Physiologic involution such as shedding of the endometrium, regression
of the lactating breast
Normal destruction of cells accompanied by replacement proliferation
such as in the gut epithelium
Involution of the thymus in early age
Pathological conditions
Anticancer drug induced cell death in tumours
Cytotoxic T cell induced cell death such as in immune rejection and
graft versus host disease
Progressive cell death and depletion of CD4+ cells in AIDs
Some forms of virus-induced cell death, such as hepatitis B or C
Pathologic atrophy of organs and tissues as a result of stimuli removal
e.g. prostatic atrophy after orchidectomy
Cell death due to injurious agents like radiation, hypoxia and mild
thermal injury
Cell death in degenerative diseases such as Alzheimer's disease and
Parkinson's disease
Cell death that occurs in heart diseases such as myocardial infarction

remarkably similar across cell types and species $[11,12]$. Usually several hours are required from the initiation of cell death to the final cellular fragmentation. However, the time taken depends on the cell type, the stimulus and the apoptotic pathway [13].

Morphological hallmarks of apoptosis in the nucleus are chromatin condensation and nuclear fragmentation, which are accompanied by rounding up of the cell, reduction in cellular volume (pyknosis) and retraction of pseudopodes [14]. Chromatin condensation starts at the periphery of the nuclear membrane, forming a crescent or ring-like structure. The chromatin further condenses until it breaks up inside a cell with an intact membrane, a feature described as karyorrhexis [15]. The plasma membrane is intact throughout the total process. At the later stage of apoptosis some of the morphological features include membrane blebbing, ultrastrutural modification of cytoplasmic organelles and a loss of membrane integrity [14]. Usually phagocytic cells engulf apoptotic cells before apoptotic bodies occur. This is the reason why apoptosis was discovered very late in the history of cell biology in 1972 and apoptotic bodies are seen in vitro under special conditions. If the remnants of apoptotic cells are not phagocytosed such as in the case of an artificial cell culture environment, they will undergo degradation that resembles necrosis and the condition is termed secondary necrosis [13].

\subsection{Biochemical changes in apoptosis}

Broadly, three main types of biochemical changes can be observed in apoptosis: 1) activation of caspases, 2) DNA and protein breakdown and 3) membrane changes and recognition by phagocytic cells [16]. Early in apoptosis, there is expression of phosphatidylserine (PS) in the outer layers of the cell membrane, which has been "flipped out" from the inner layers. This allows early recognition of dead cells by macrophages, resulting in phagocytosis without the release of proinflammatory cellular components [17]. This is followed by a characteristic breakdown of DNA into large 50 to 300 kilobase pieces [18]. Later, there is internucleosomal cleavage of DNA into oligonucleosomes in multiples of 180 to 200 base pairs by endonucleases. Although this feature is characteristic of apoptosis, it is not specific as the typical DNA ladder in agarose gel electrophoresis can be seen in necrotic cells as well [19]. Another specific feature of apoptosis is the activation of a group of enzymes belonging to the cysteine protease family named caspases. The "c" of "caspase" refers to a cysteine protease, while the "aspase" refers to the enzyme's unique property to cleave after aspartic acid residues [16]. Activated caspases cleave many vital cellular proteins and break up the nuclear scaffold and cytoskeleton. They also activate DNAase, which further degrade nuclear DNA [20]. Although the biochemical changes explain in part some of the morphological changes in apoptosis, it is important to note that biochemical analyses of DNA fragmentation or caspase activation should not be used to define apoptosis, as apoptosis can occur without oligonucleosomal DNA fragmentation and can be caspase-independent [21]. While many biochemical assays and experiments have been used in the detection of apoptosis, the Nomenclature Committee on Cell Death (NCCD) has proposed that the classification of cell death modalities should rely purely on morphological criteria because there is no clear-cut equivalence between ultrastructural changes and biochemical cell death characteristics [21].

\subsection{Mechanisms of apoptosis}

Understanding the mechanisms of apoptosis is crucial and helps in the understanding of the pathogenesis of conditions as a result of disordered apoptosis. This in turn, may help in the development of drugs that target certain apoptotic genes or pathways. Caspases are central to the mechanism of apoptosis as they are both the initiators and executioners. There are three pathways by which caspases can be activated. The two commonly described initiation pathways are the intrinsic (or mitochondrial) and extrinsic (or death receptor) pathways of apoptosis (Figure 1). Both pathways eventually lead to a common pathway or the execution phase of apoptosis. A third less well-known initiation pathway is the intrinsic endoplasmic reticulum pathway [22]. 


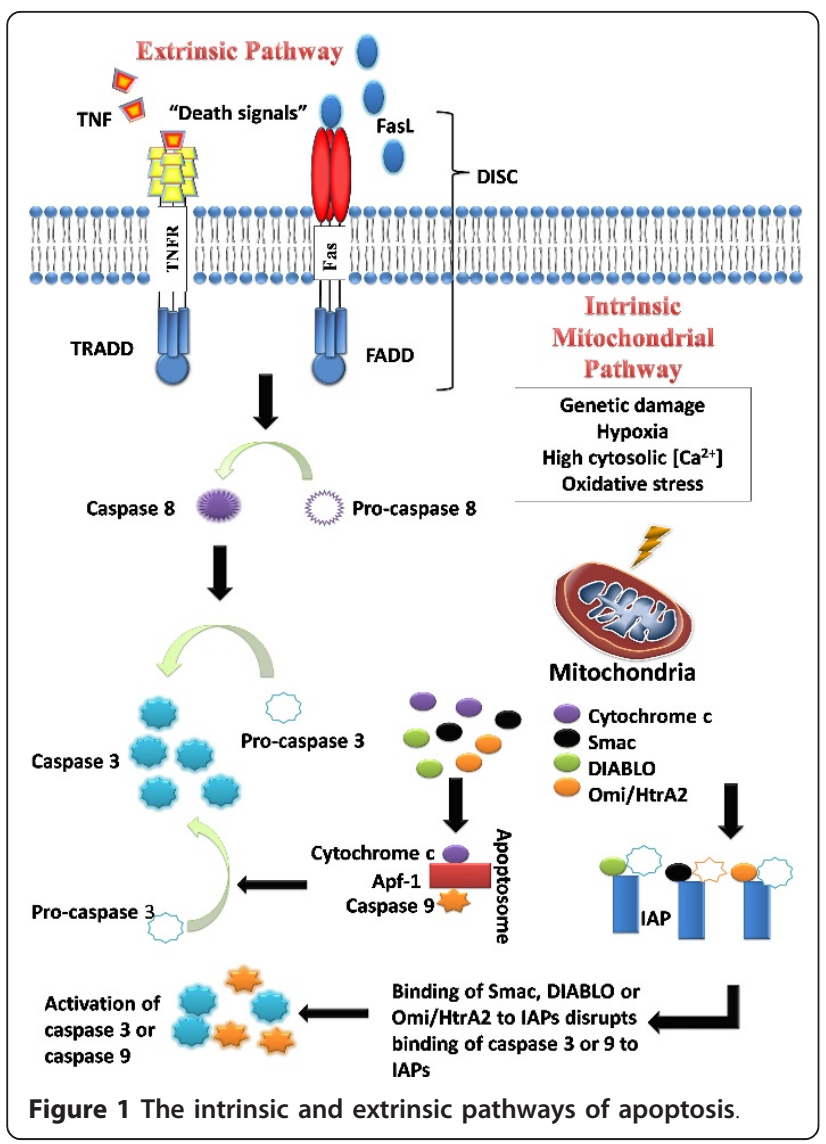

\subsubsection{The extrinsic death receptor pathway}

The extrinsic death receptor pathway, as its name implies, begins when death ligands bind to a death receptor. Although several death receptors have been described, the best known death receptors is the type 1 TNF receptor (TNFR1) and a related protein called Fas (CD95) and their ligands are called TNF and Fas ligand (FasL) respectively [17]. These death receptors have an intracellular death domain that recruits adapter proteins such as TNF receptor-associated death domain (TRADD) and Fas-associated death domain (FADD), as well as cysteine proteases like caspase 8 [23]. Binding of the death ligand to the death receptor results in the formation of a binding site for an adaptor protein and the whole ligand-receptor-adaptor protein complex is known as the death-inducing signalling complex (DISC) [22]. DISC then initiates the assembly and activation of pro-caspase 8 . The activated form of the enzyme, caspase 8 is an initiator caspase, which initiates apoptosis by cleaving other downstream or executioner caspases [24].

\subsubsection{The intrinsic mitochondrial pathway}

As its name implies, the intrinsic pathway is initiated within the cell. Internal stimuli such as irreparable genetic damage, hypoxia, extremely high concentrations of cytosolic $\mathrm{Ca}^{2+}$ and severe oxidative stress are some triggers of the initiation of the intrinsic mitochondrial pathway [24]. Regardless of the stimuli, this pathway is the result of increased mitochondrial permeability and the release of pro-apoptotic molecules such as cytochrome-c into the cytoplasm [25]. This pathway is closely regulated by a group of proteins belonging to the Bcl-2 family, named after the BCL2 gene originally observed at the chromosomal breakpoint of the translocation of chromosome 18 to 14 in follicular non-Hodgkin lymphoma [26]. There are two main groups of the $\mathrm{Bcl}-2$ proteins, namely the pro-apoptotic proteins (e.g. Bax, Bak, Bad, Bcl-Xs, Bid, Bik, Bim and Hrk) and the anti-apoptotic proteins (e.g. Bcl-2, Bcl- $\mathrm{X}_{\mathrm{L}}, \mathrm{Bcl}-\mathrm{W}, \mathrm{Bfl}-1$ and Mcl-1) [27]. While the anti-apoptotic proteins regulate apoptosis by blocking the mitochondrial release of cytochrome-c, the pro-apoptotic proteins act by promoting such release. It is not the absolute quantity but rather the balance between the pro- and anti-apoptotic proteins that determines whether apoptosis would be initiated [27]. Other apoptotic factors that are released from the mitochondrial intermembrane space into the cytoplasm include apoptosis inducing factor (AIF), second mitochondria-derived activator of caspase (Smac), direct IAP Binding protein with Low pI (DIABLO) and Omi/high temperature requirement protein A (HtrA2) [28]. Cytoplasmic release of cytochrome c activates caspase 3 via the formation of a complex known as apoptosome which is made up of cytochrome c, Apaf- 1 and caspase 9 [28]. On the other hand, Smac/DIABLO or Omi/HtrA2 promotes caspase activation by binding to inhibitor of apoptosis proteins (IAPs) which subsequently leads to disruption in the interaction of IAPs with caspase-3 or $-9[28,29]$.

\subsubsection{The common pathway}

The execution phase of apoptosis involves the activation of a series of caspases. The upstream caspase for the intrinsic pathway is caspase 9 while that of the extrinsic pathway is caspase 8 . The intrinsic and extrinsic pathways converge to caspase 3 . Caspase 3 then cleaves the inhibitor of the caspase-activated deoxyribonuclease, which is responsible for nuclear apoptosis [30]. In addition, downstream caspases induce cleavage of protein kinases, cytoskeletal proteins, DNA repair proteins and inhibitory subunits of endonucleases family. They also have an effect on the cytoskeleton, cell cycle and signalling pathways, which together contribute to the typical morphological changes in apoptosis [30].

\subsubsection{The intrinsic endoplasmic reticulum pathway}

This intrinsic endoplasmic reticulum (ER) pathway is a third pathway and is less well known. It is believed to be caspase 12-dependent and mitochondria-independent [31]. When the ER is injured by cellular stresses like hypoxia, free radicals or glucose starvation, there is 
unfolding of proteins and reduced protein synthesis in the cell, and an adaptor protein known as TNF receptor associated factor 2 (TRAF2) dissociates from procaspase-12, resulting in the activation of the latter [22].

\section{Apoptosis and carcinogenesis}

Cancer can be viewed as the result of a succession of genetic changes during which a normal cell is transformed into a malignant one while evasion of cell death is one of the essential changes in a cell that cause this malignant transformation [32]. As early as the 1970's, Kerr et al had linked apoptosis to the elimination of potentially malignant cells, hyperplasia and tumour progression [8]. Hence, reduced apoptosis or its resistance plays a vital role in carcinogenesis. There are many ways a malignant cell can acquire reduction in apoptosis or apoptosis resistance. Generally, the mechanisms by which evasion of apoptosis occurs can be broadly dividend into: 1) disrupted balance of pro-apoptotic and anti-apoptotic proteins, 2) reduced caspase function and 3 ) impaired death receptor signalling. Figure 2 summarises the mechanisms that contribute to evasion of apoptosis and carcinogenesis.

\subsection{Disrupted balance of pro-apoptotic and anti-apoptotic proteins}

Many proteins have been reported to exert pro- or antiapoptotic activity in the cell. It is not the absolute quantity but rather the ratio of these pro-and anti-apoptotic proteins that plays an important role in the regulation of cell death. Besides, over- or under-expression of certain genes (hence the resultant regulatory proteins) have been found to contribute to carcinogenesis by reducing apoptosis in cancer cells.

\subsubsection{The BCl-2 family of proteins}

The Bcl-2 family of proteins is comprised of pro-apoptotic and anti-apoptotic proteins that play a pivotal role in the regulation of apoptosis, especially via the intrinsic pathway as they reside upstream of irreversible cellular damage and act mainly at the mitochondria level [33]. Bcl-2 was the first protein of this family to be identified more than 20 years ago and it is encoded by the BCL2

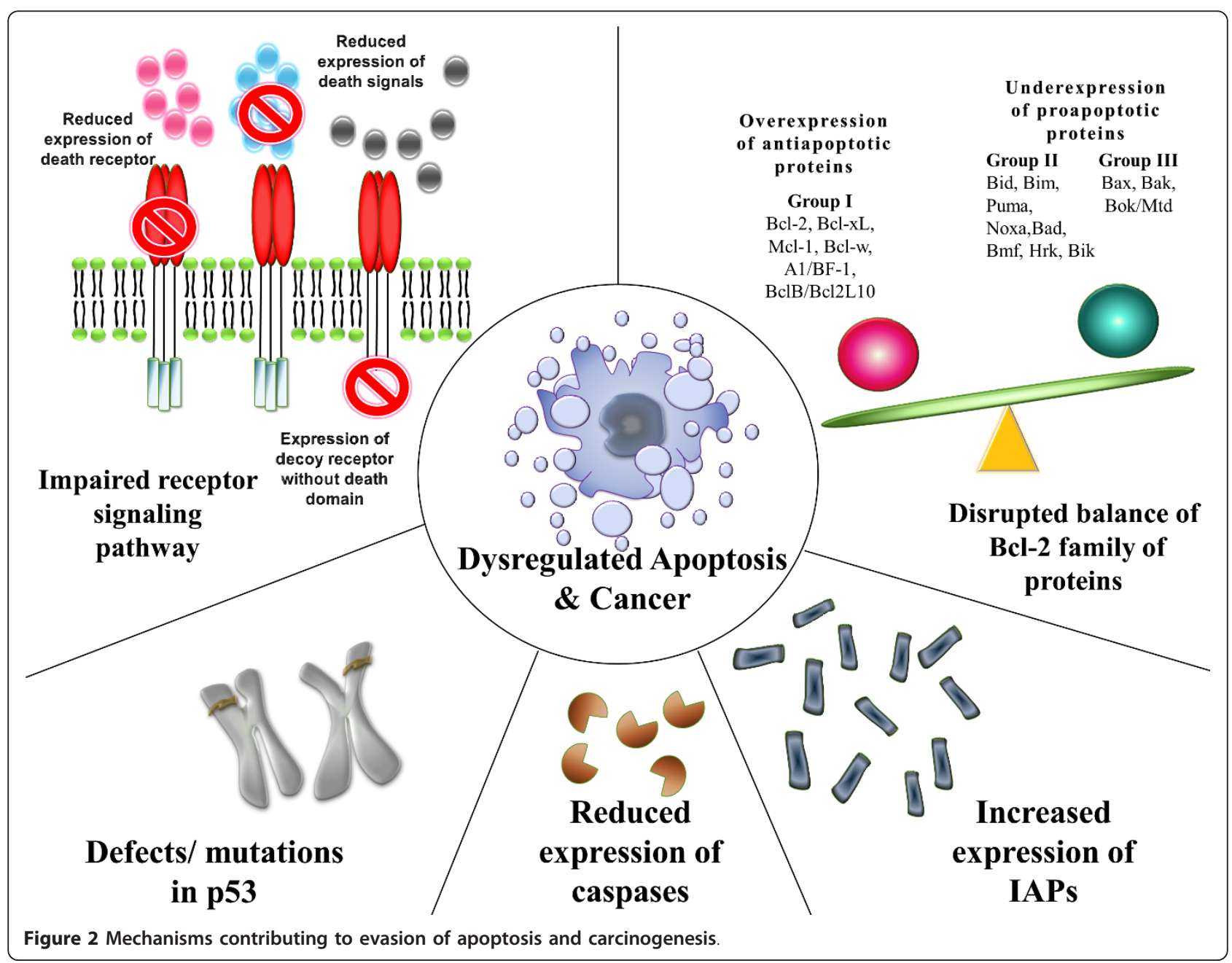


gene, which derives its name from B-cell lymphoma 2, the second member of a range of proteins found in human B-cell lymphomas with the $t(14 ; 18)$ chromosomal translocation [26].

All the Bcl-2 members are located on the outer mitochondrial membrane. They are dimmers which are responsible for membrane permeability either in the form of an ion channel or through the creation of pores [34]. Based of their function and the Bcl-2 homology (BH) domains the Bcl-2 family members are further divided into three groups [35]. The first group are the anti-apoptotic proteins that contain all four $\mathrm{BH}$ domains and they protect the cell from apoptotic stimuli. Some examples are Bcl-2, Bcl-xL, Mcl-1, Bcl-w, A1/Bfl-1, and $\mathrm{Bcl}-\mathrm{B} / \mathrm{Bcl} 2 \mathrm{~L} 10$. The second group is made up of the $\mathrm{BH}-3$ only proteins, so named because in comparison to the other members, they are restricted to the $\mathrm{BH} 3$ domain. Examples in this group include Bid, Bim, Puma, Noxa, Bad, Bmf, Hrk, and Bik. In times of cellular stresses such as DNA damage, growth factor deprivation and endoplasmic reticulum stress, the $\mathrm{BH} 3$-only proteins, which are initiators of apoptosis, are activated. Therefore, they are pro-apoptotic. Members of the third group contain all four $\mathrm{BH}$ domains and they are also pro-apoptotic. Some examples include Bax, Bak, and Bok/Mtd [35].

When there is disruption in the balance of anti-apoptotic and pro-apoptotic members of the Bcl-2 family, the result is dysregulated apoptosis in the affected cells. This can be due to an overexpression of one or more anti-apoptotic proteins or an underexpression of one or more pro-apoptotic proteins or a combination of both. For example, Raffo et al showed that the overexpression of Bcl-2 protected prostate cancer cells from apoptosis [36] while Fulda et al reported Bcl-2 overexpression led to inhibition of TRAIL-induced apoptosis in neuroblastoma, glioblastoma and breast carcinoma cells [37]. Overexpression of $\mathrm{Bcl}-\mathrm{xL}$ has also been reported to confer a multi-drug resistance phenotype in tumour cells and prevent them from undergoing apoptosis [38]. In colorectal cancers with microsatellite instability, on the other hand, mutations in the bax gene are very common. Miquel et al demonstrated that impaired apoptosis resulting from $\operatorname{bax}(\mathrm{G}) 8$ frameshift mutations could contribute to resistance of colorectal cancer cells to anticancer treatments [39]. In the case of chronic lymphocytic leukaemia (CLL), the malignant cells have an anti-apoptotic phenotype with high levels of anti-apoptotic Bcl-2 and low levels of pro-apoptotic proteins such as Bax in vivo. Leukaemogenesis in CLL is due to reduced apoptosis rather than increased proliferation in vivo [40]. Pepper et al reported that B-lymphocytes in CLL showed an increased $\mathrm{Bcl}-2 / \mathrm{Bax}$ ratio in patients with CLL and that when these cells were cultured in vitro, drug- induced apoptosis in B-CLL cells was inversely related to $\mathrm{Bcl}-2 / \mathrm{Bax}$ ratios [41].

\subsection{2 p53}

The p53 protein, also called tumour protein 53 (or TP 53 ), is one of the best known tumour suppressor proteins encoded by the tumour suppressor gene TP53 located at the short arm of chromosome 17 (17p13.1). It is named after its molecular weights, i.e., $53 \mathrm{kDa}$ [42]. It was first identified in 1979 as a transformation-related protein and a cellular protein accumulated in the nuclei of cancer cells binding tightly to the simian virus 40 (SV40) large $\mathrm{T}$ antigen. Initially, it was found to be weakly-oncogenic. It was later discovered that the oncogenic property was due to a p53 mutation, or what was later called a "gain of oncogenic function" [43]. Since its discovery, many studies have looked into its function and its role in cancer. It is not only involved in the induction of apoptosis but it is also a key player in cell cycle regulation, development, differentiation, gene amplification, DNA recombination, chromosomal segregation and cellular senescence [44] and is called the "guardian of the genome" [45].

Defects in the p53 tumour suppressor gene have been linked to more than $50 \%$ of human cancers [43]. Recently, Avery-Kieida et al reported that some target genes of p53 involved in apoptosis and cell cycle regulation are aberrantly expressed in melanoma cells, leading to abnormal activity of p53 and contributing to the proliferation of these cells [46]. In a mouse model with an $N$-terminal deletion mutant of p53 $(\Delta 122 \mathrm{p} 53)$ that corresponds to $\Delta 133 \mathrm{p} 53$, Slatter et al demonstrated that these mice had decreased survival, a different and more aggressive tumor spectrum, a marked proliferative advantage on cells, reduced apoptosis and a profound proinflammatory phenotype [47]. In addition, it has been found that when the p53 mutant was silenced, such down-regulation of mutant p53 expression resulted in reduced cellular colony growth in human cancer cells, which was found to be due to the induction of apoptosis [48].

\subsubsection{Inhibitor of apoptosis proteins (IAPs)}

The inhibitor of apoptosis proteins are a group of structurally and functionally similar proteins that regulate apoptosis, cytokinesis and signal transduction. They are characterised by the presence of a baculovirus IAP repeat (BIR) protein domain [29]. To date eight IAPs have been identified, namely, NAIP (BIRC1), c-IAP1 (BIRC2), c-IAP2 (BIRC3), X-linked IAP (XIAP, BIRC4), Survivin (BIRC5), Apollon (BRUCE, BIRC6), Livin/MLIAP (BIRC7) and IAP-like protein 2 (BIRC8) [49]. IAPs are endogenous inhibitors of caspases and they can inhibit caspase activity by binding their conserved BIR domains to the active sites of caspases, by promoting degradation of active caspases or by keeping the caspases away from their substrates [50]. 
Dysregulated IAP expression has been reported in many cancers. For example, Lopes et al demonstrated abnormal expression of the IAP family in pancreatic cancer cells and that this abnormal expression was also responsible for resistance to chemotherapy. Among the IAPs tested, the study concluded that drug resistance correlated most significantly with the expression of cIAP-2 in pancreatic cells [51]. On the other hand, Livin was demonstrated to be highly expressed in melanoma and lymphoma [52,53] while Apollon, was found to be upregulated in gliomas and was responsible for cisplatin and camptothecin resistance [54]. Another IAP, Survivin, has been reported to be overexpressed in various cancers. Small et al. observed that transgenic mice that overexpressed Survivin in haematopoietic cells were at an increased risk of haematological malignancies and that haematopoietic cells engineered to overexpress Survivin were less susceptible to apoptosis [55]. Survivin, together with XIAP, was also found to be overexpressed in nonsmall cell lung carcinomas (NSCLCs) and the study concluded that the overexpression of Survivin in the majority of NSCLCs together with the abundant or upregulated expression of XIAP suggested that these tumours were endowed with resistance against a variety of apoptosis-inducing conditions [56].

\subsection{Reduced capsase activity}

The caspases can be broadly classified into two groups: 1 ) those related to caspase 1 (e.g. caspase-1, -4, -5, -13, and -14) and are mainly involved in cytokine processing during inflammatory processes and 2) those that play a central role in apoptosis (e.g. caspase-2, -3. -6, -7,-8, -9 and -10$)$. The second group can be further classified into 1) initiator caspases (e.g. caspase-2, -8, -9 and -10) which are primarily responsible for the initiation of the apoptotic pathway and 2) effector caspases (caspase-3, -6 and -7 ) which are responsible in the actual cleavage of cellular components during apoptosis [57]. As mentioned in Section 2.2, caspases remain one of the important players in the initiation and execution of apoptosis. It is therefore reasonable to believe that low levels of caspases or impairment in caspase function may lead to a decreased in apoptosis and carcinogenesis.

In one study, downregulation of caspase-9 was found to be a frequent event in patients with stage II colorectal cancer and correlates with poor clinical outcome [58]. In another study, Devarajan et al observed that caspases-3 mRNA levels in commercially available total RNA samples from breast, ovarian, and cervical tumuors were either undetectable (breast and cervical) or substantially decreased (ovarian) and that the sensitivity of caspase-3-deficient breast cancer (MCF-7) cells to undergo apoptosis in response to anticancer drug or other stimuli of apoptosis could be enhanced by restoring caspase- 3 expression, suggesting that the loss of caspases-3 expression and function could contribute to breast cancer cell survival [59]. In some instances, more than one caspase can be downregulated, contributing to tumour cell growth and development. In a cDNA array differential expression study, Fong et al observed a codownregulation of both capase- 8 and -10 and postulated that it may contribute to the pathogenesis of choriocarcinoma [60].

\subsection{Impaired death receptor signalling}

Death receptors and ligands of the death receptors are key players in the extrinsic pathway of apoptosis. Other than TNFR1 (also known as DR 1) and Fas (also known as DR2, CD95 or APO-1) mentioned in Section 2.3, examples of death receptors include DR3 (or APO-3), DR4 [or TNF-related apoptosis inducing ligand receptor 1 (TRAIL-1) or APO-2], DR5 (or TRAIL-2), DR 6, ectodysplasin A receptor (EDAR) and nerve growth factor receptor (NGFR) [61]. These receptors posses a death domain and when triggered by a death signal, a number of molecules are attracted to the death domain, resulting in the activation of a signalling cascade. However, death ligands can also bind to decoy death receptors that do not posses a death domain and the latter fail to form signalling complexes and initiate the signalling cascade [61]

Several abnormalities in the death signalling pathways that can lead to evasion of the extrinsic pathway of apoptosis have been identified. Such abnormalities include downregulation of the receptor or impairment of receptor function regardless of the mechanism or type of defects, as well as a reduced level in the death signals, all of which contribute to impaired signalling and hence a reduction of apoptosis. For instance, downregulation of receptor surface expression has been indicated in some studies as a mechanism of acquired drug resistance. A reduced expression of CD95 was found to play a role in treatment-resistant leukaemia [62] or neuroblastoma [63] cells. Reduced membrane expression of death receptors and abnormal expression of decoy receptors have also been reported to play a role in the evasion of the death signalling pathways in various cancers [64]. In a study carried out to examine if changes in death ligand and death receptor expression during different stages of cervical carcinogenesis were related to an imbalance between proliferation and apoptosis, Reesink-Peters et al concluded that the loss of Fas and the dysregulation of FasL, DR4, DR5, and tumor necrosis factor-related apoptosis-inducing ligand (TRAIL) in the cervical intraepithelial neoplasia (CIN)-cervical cancer sequence might be responsible for cervical carcinogenesis [65]. 


\section{Targeting apoptosis in cancer treatment}

Like a double-edged sword, every defect or abnormality along the apoptotic pathways may also be an interesting target of cancer treatment. Drugs or treatment strategies that can restore the apoptotic signalling pathways towards normality have the potential to eliminate cancer cells, which depend on these defects to stay alive. Many recent and important discoveries have opened new doors into potential new classes of anticancer drugs. This Section emphasises on new treatment options targeting some of the apoptotic defects mentioned in Section 3. A summary of these drugs and treatment strategies is given in Table 2.

\subsection{Targeting the $\mathrm{Bcl}-2$ family of proteins}

Some potential treatment strategies used in targeting the Bcl-2 family of proteins include the use of therapeutic agents to inhibit the Bcl-2 family of anti-apoptotic proteins or the silencing of the upregulated anti-apoptotic proteins or genes involved.

\subsubsection{Agents that target the $\mathrm{BCl}-2$ family of proteins}

One good example of these agents is the drug oblimersen sodium, which is a Bcl-2 antisence oblimer, the first agent targeting $\mathrm{Bcl}-2$ to enter clinical trial. The drug has been reported to show chemosensitising effects in combined treatment with conventional anticancer drugs in chronic myeloid leukaemia patients and an improvement in survival in these patients [66,67]. Other examples included in this category are the small molecule inhibitors of the Bcl-2 family of proteins. These can be further divided into: 1) those molecules that affect gene or protein expression and 2) those acting on the proteins themselves. Examples for the first group include sodium butyrate, depsipetide, fenretinide and flavipirodol while the second group includes gossypol, ABT-737, ABT-263, GX15-070 and HA14-1 (reviewed by Kang and Reynold, 2009 [68]).

Some of these small molecules belong to yet another class of drugs called BH3 mimetics, so named because they mimic the binding of the $\mathrm{BH} 3$-only proteins to the hydrophobic groove of anti-apoptotic proteins of the $\mathrm{Bcl}-2$ family. One classical example of a $\mathrm{BH} 3$ mimetic is ABT-737, which inhibits anti-apoptotic proteins such as Bcl-2, Bcl-xL, and Bcl-W. It was shown to exhibit cytotoxicity in lymphoma, small cell lung carcinoma cell line and primary patient-derived cells and caused regression of established tumours in animal models with a high percentage of cure [69]. Other BH3 mimetics such as ATF4, ATF3 and NOXA have been reported to bind to and inhibit Mcl-1 [70].

\subsubsection{Silencing the anti-apoptotic proteins/genes}

Rather than using drugs or therapeutic agents to inhibit the anti-apoptotic members of the Bcl-2 family, some studies have demonstrated that by silencing genes coding for the Bcl-2 family of anti-apoptotic proteins, an increase in apoptosis could be achieved. For example, the use of Bcl-2 specific siRNA had been shown to specifically inhibit the expression of target gene in vitro and in vivo with anti-proliferative and pro-apoptotic effects observed in pancreatic carcinoma cells [71]. On the other hand, Wu et al demonstrated that by silencing Bmi-1 in MCF breast cancer cells, the expression of pAkt and Bcl-2 was downregulated, rendering these cells more sensitive to doxorubicin as evidenced by an increase in apoptotic cells in vitro and in vivo [72].

\subsection{Targeting p53}

Many p53-based strategies have been investigated for cancer treatment. Generally, these can be classified into three broad categories: 1) gene therapy, 2) drug therapy and 3) immunotherapy.

\subsection{1 p53-based gene therapy}

The first report of p53 gene therapy in 1996 investigated the use of a wild-type p53 gene containing retroviral vector injected into tumour cells of non-small cell lung carcinoma derived from patients and showed that the use of p53-based gene therapy may be feasible [73]. As the use of the p53 gene alone was not enough to eliminate all tumour cells, later studies have investigated the use of p53 gene therapy concurrently with other anticancer strategies. For example, the introduction of wildtype p53 gene has been shown to sensitise tumour cells of head and neck, colorectal and prostate cancers and glioma to ionising radiation [74]. Although a few studies managed to go as far as phase III clinical trials, no final approval from the FDA has been granted so far [75]. Another interesting p53 gene-based strategy was the use of engineered viruses to eliminate p53-deficient cells. One such example is the use of a genetically engineered oncolytic adenovirus, ONYX-015, in which the E1B-55 $k D a$ gene has been deleted, giving the virus the ability to selectively replicate in and lyse tumour cells deficient in $\mathrm{p} 53$ [76].

\subsection{2 p53-based drug therapy}

Several drugs have been investigated to target p53 via different mechanisms. One class of drugs are small molecules that can restore mutated p53 back to their wild-type functions. For example, Phikan083, a small molecule and carbazole derivative, has been shown to bind to and restore mutant p53 [77]. Another small molecule, CP-31398, has been found to intercalate with DNA and alter and destabilise the DNA-p53 core domain complex, resulting in the restoration of unstable p53 mutants [78]. Other drugs that have been used to target p53 include the nutlins, MI-219 and the tenovins. Nutlins are analogues of cis-imidazoline, which inhibit the MSM2-p53 interaction, stabilise p53 and selectively induce senescence in cancer cells [79] while MI-219 was 
Table 2 Summary of treatment strategies targeting apoptosis

\begin{tabular}{|c|c|c|}
\hline Treatment strategy & Remarks & Author/reference \\
\hline \multicolumn{3}{|l|}{$\begin{array}{l}\text { Targeting the } \mathrm{Bcl}-2 \text { family of } \\
\text { proteins }\end{array}$} \\
\hline \multirow{7}{*}{$\begin{array}{l}\text { Agents that target the } \mathrm{BCl}-2 \\
\text { family proteins }\end{array}$} & Oblimersen sodium & \\
\hline & $\begin{array}{l}\text { Reported to show chemosensitising effects in combined treatment with } \\
\text { conventional anticancer drugs in chronic myeloid leukaemia patients and an } \\
\text { improvement in survival in these patients }\end{array}$ & $\begin{array}{l}\text { Rai et al., } 2008 \text { [66], Abou- } \\
\text { Nassar and Brown, } 2010[67]\end{array}$ \\
\hline & Small molecule inhibitors of the $\mathrm{BCl}-2$ family of proteins & \\
\hline & $\begin{array}{l}\text { Molecules reported to affect gene or protein expression include sodium butyrate, } \\
\text { depsipetide, fenretinide and flavipirodo. Molecules reported to act on the proteins } \\
\text { themselves include gossypol, ABT-737, ABT-263, GX15-070 and HA14-1 }\end{array}$ & Kang and Reynold, 2009 [68] \\
\hline & BH3 mimetics & \\
\hline & $\begin{array}{l}\text { ABT-737 reported to inhibit anti-apoptotic proteins such as } \mathrm{BCl}-2, \mathrm{BCl}-\mathrm{xL} \text {, and } \mathrm{BCl}-\mathrm{W} \\
\text { and to exhibit cytotoxicity in lymphoma, small cell lung carcinoma cell line and } \\
\text { primary patient-derived cells }\end{array}$ & Oltersdorf et al., 2005 [69] \\
\hline & ATF4, ATF3 and NOXA reported to bind to and inhibit Mcl-1 & Albershardt et al., 2011 [70] \\
\hline \multirow[t]{2}{*}{$\begin{array}{l}\text { Silencing the Bcl family anti- } \\
\text { apoptotic proteins/genes }\end{array}$} & $\begin{array}{l}\text { Bcl-2 specific siRNA reported to specifically inhibit the expression of target gene in } \\
\text { vitro and in vivo with anti-proliferative and pro-apoptotic effects observed in } \\
\text { pancreatic carcinoma cells }\end{array}$ & Ocker et al., 2005 [71] \\
\hline & $\begin{array}{l}\text { Silencing Bmi-1 in MCF breast cancer cells reported to downregulate the } \\
\text { expression of pAkt and Bcl-2 and to increase sensitivity of these cells to } \\
\text { doxorubicin with an increase in apoptotic cells in vitro and in vivo }\end{array}$ & Wu et al., 2011 [72] \\
\hline
\end{tabular}

Targeting p53

p53-based gene therapy
First report on the use of a wild-type p53 gene containing retroviral vector injected Roth et al., 1996 [73] into tumour cells of non-small cell lung carcinoma derived from patients. The use of p53-based gene therapy was reported to be feasible.

Introduction of wild type p53 gene reported to sensitise tumour cells of head and Chène, 2001 [74] neck, colorectal and prostate cancers and glioma to ionising radiation

Genetically engineered oncolytic adenovirus, ONYX-015 reported to selectively Nemunaitis et al., 2009 [76] replicate in and lyse tumour cells deficient in p53
Boeckler et al., 2008 [77]

Rippin et al., 2002 [78]

Shangery and Wang, 2008 [79]

Shangery et al., 2008 [80]

Lain et al., 2008 [81]

Kuball et al., 2002 [82]

Svane et al., 2004 [83]

Clinical and p53-specific T cell responses observed in patients given p53 peptide pulsed dendritic cells in a phase I clinical trial

\section{Targeting IAPS}

Targeting XIAP
Antisense approach

Reported to result in an improved in vivo tumour control by radiotherapy

Concurrent use of antisense oligonucleotides and chemotherapy reported to

Cao et al., 2004 [86]

exhibit enhanced chemotherapeutic activity in lung cancer cells in vitro and in vivo

siRNA approach

siRNA targeting of XIAP reported to increase radiation sensitivity of human cancer cells independent of TP53 status

Targeting XIAP or Survivin by siRNAs sensitised hepatoma cells to death receptorand chemotherapeutic agent-induced cell death
Hu et al., 2003 [87]

Ohnishi et al., 2006 [88]

Yamaguchi et al., 2005 [89] Antisense approach 


\begin{tabular}{|c|c|c|}
\hline & $\begin{array}{l}\text { Transfection of anti-sense Survivin into YUSAC-2 and LOX malignant melanoma } \\
\text { cells reported to result in spontaneous apoptosis }\end{array}$ & Grossman et al., 1999 [90] \\
\hline & $\begin{array}{l}\text { Reported to induce apoptosis and sensitise head and neck squamous cell } \\
\text { carcinoma cells to chemotherapy }\end{array}$ & Sharma et al., 2005 [91] \\
\hline & $\begin{array}{l}\text { Reported to inhibit growth and proliferation of medullary thyroid carcinoma cells } \\
\text { SiRNA approach }\end{array}$ & Du et al., 2006 [92] \\
\hline & $\begin{array}{l}\text { Reported o downregulate Survivin and diminish radioresistance in pancreatic } \\
\text { cancer cells }\end{array}$ & Kami et al., 2005 [93] \\
\hline & $\begin{array}{l}\text { Reported to inhibit proliferation and induce apoptosis in SPCA1 and SH77 human } \\
\text { lung adenocarcinoma cells }\end{array}$ & Liu et al., 2011 [94] \\
\hline & $\begin{array}{l}\text { Reported to suppress Survivin expression, inhibit cell proliferation and enhance } \\
\text { apoptosis in SKOV3/DDP ovarian cancer cells }\end{array}$ & Zhang et al., 2009 [95] \\
\hline & Reported to enhance the radiosensitivity of human non-small cell lung cancer cells & Yang et al., 2010 [96] \\
\hline \multirow[t]{4}{*}{ Other IAP antagonists } & Small molecules antagonists & \\
\hline & $\begin{array}{l}\text { Cyclin-dependent kinase inhibitors and Hsp90 inhibitors and gene therapy } \\
\text { attempted in targeting Survivin in cancer therapy }\end{array}$ & Pennati et al., 2007 [97] \\
\hline & $\begin{array}{l}\text { Cyclopeptidic Smac mimetics } 2 \text { and } 3 \text { report to bind to XIAP and CIAP-1/2 and } \\
\text { restore the activities of caspases- } 9 \text { and } 3 /-7 \text { inhibited by XIAP }\end{array}$ & Sun et al., 2010 [98] \\
\hline & $\begin{array}{l}\text { SM-164 reported to enhance TRAIL activity by concurrently targeting XIAP and } \\
\text { CIAP1 }\end{array}$ & Lu et al., 2011 [99] \\
\hline \multicolumn{3}{|l|}{ Targeting caspases } \\
\hline \multirow[t]{2}{*}{ Caspase-based drug therapy } & Apoptin reported to selectively induce apoptosis in malignant but not normal cells & Rohn et al, 2004 [100] \\
\hline & $\begin{array}{l}\text { Small molecules caspase activators reported to lower the activation threshold of } \\
\text { caspase or activate caspase, contributing to an increased drug sensitivity of cancer } \\
\text { cells }\end{array}$ & Philchenkov et al., 2004 [101] \\
\hline \multirow[t]{3}{*}{ Caspase-based gene therapy } & $\begin{array}{l}\text { Human caspase-3 gene therapy used in addition to etoposide treatment in an } \\
\text { AH130 liver tumour model reported to induce extensive apoptosis and reduce } \\
\text { tumour volume }\end{array}$ & Yamabe et al., 1999 [102] \\
\hline & $\begin{array}{l}\text { Gene transfer of constitutively active caspse-3 into HuH7 human hepatoma cells } \\
\text { reported to selectively induce apoptosis }\end{array}$ & Cam et al., 2005 [103] \\
\hline & $\begin{array}{l}\text { A recombinant adenovirus carrying immunocaspase } 3 \text { reported to exert anticancer } \\
\text { effect in hepatocellular carcinoma in vitro and in vivo }\end{array}$ & Li et al., 2007 [104] \\
\hline
\end{tabular}

reported to disrupt the MDM2-p53 interaction, resulting in inhibition of cell proliferation, selective apoptosis in tumour cells and complete tumour growth inhibition [80]. The tenovins, on the other hand, are small molecule p53 activators, which have been shown to decrease tumour growth in vivo [81].

\subsection{3 p53-based immunotherapy}

Several clinical trials have been carried out using p53 vaccines. In a clinical trial by Kuball et al, six patients with advanced-stage cancer were given vaccine containing a recombinant replication-defective adenoviral vector with human wild-type p53. When followed up at 3 months post immunisation, four out of the six patients had stable disease. However, only one patient had stable disease from 7 months onwards [82]. Other than viral-based vaccines, dendritic-cell based vaccines have also been attempted in clinical trials. Svane et al tested the use of p53 peptide pulsed dendritic cells in a phase I clinical trial and reported a clinical response in two out of six patients and p53-specific $\mathrm{T}$ cell responses in three out of six patients [83]. Other vaccines that have been used including short peptide- based and long peptide-based vaccines (reviewed by Vermeij R et al., 2011 [84]).

\subsection{Targeting the IAPs}

\subsubsection{Targeting XIAP}

When designing novel drugs for cancers, the IAPs are attractive molecular targets. So far, XIAP has been reported to be the most potent inhibitor of apoptosis among all the IAPs. It effectively inhibits the intrinsic as well as extrinsic pathways of apoptosis and it does so by binding and inhibiting upstream caspase- 9 and the downstream caspases-3 and -7 [85]. Some novel therapy targeting XIAP include antisense strategies and short interfering RNA (siRNA) molecules. Using the antisense approach, inhibition of XIAP has been reported to result in an improved in vivo tumour control by radiotherapy [86]. When used together with anticancer drugs XIAP antisense oligonucleotides have been demonstrated to exhibit enhanced chemotherapeutic activity in lung cancer cells in vitro and in vivo [87]. On the other hand, Ohnishi et al reported that siRNA targeting of XIAP increased radiation sensitivity of human cancer cells 
independent of TP53 status [88] while Yamaguchi et al reported that targeting XIAP or Survivin by siRNAs sensitise hepatoma cells to death receptor- and chemotherapeutic agent-induced cell death [89].

\subsubsection{Targeting Survivin}

Many studies have investigated various approaches targeting Survivin for cancer intervention. One example is the use of antisense oligonucleotides. Grossman et al was among the first to demonstrate the use of the antisense approach in human melanoma cells. It was shown that transfection of anti-sense Survivin into YUSAC-2 and LOX malignant melanoma cells resulted in spontaneous apoptosis in these cells [90]. The anti-sense approach has also been applied in head and neck squamous cell carcinoma and reported to induce apoptosis and sensitise these cells to chemotherapy [91] and in medullary thyroid carcinoma cells, and was found to inhibit growth and proliferation of these cells [92]. Another approach in targeting Survivin is the use of siRNAs, which have been shown to downregulate Survivin and diminish radioresistance in pancreatic cancer cells [93], to inhibit proliferation and induce apoptosis in SPCA1 and SH77 human lung adenocarcinoma cells [94], to suppress Survivin expression, inhibit cell proliferation and enhance apoptosis in SKOV3/DDP ovarian cancer cells [95] as well as to enhance the radiosensitivity of human non-small cell lung cancer cells [96]. Besides, small molecules antagonists of Survivin such as cyclin-dependent kinase inhibitors and Hsp90 inhibitors and gene therapy have also been attempted in targeting Survivin in cancer therapy (reviewed by Pennati et al., 2007 [97]).

\subsubsection{Other IAP antagonists}

Other IAP antagonists include peptidic and non-peptidic small molecules, which act as IAP inhibitors. Two cyclopeptidic Smac mimetics, 2 and 3, which were found to bind to XIAP and CIAP- $1 / 2$ and restore the activities of caspases- 9 and 3/-7 inhibited by XIAP were amongst the many examples [98]. On the other hand, SM-164, a non-peptidic IAP inhibitor was reported to strongly enhance TRAIL activity by concurrently targeting XIAP and CIAP1 [99].

\subsection{Targeting caspases}

\subsubsection{Caspase-based drug therapy}

Several drugs have been designed to synthetically activate caspases. For example, Apoptin is a caspase-inducing agent which was initially derived from chicken anaemia virus and had the ability to selectively induce apoptosis in malignant but not normal cells [100]. Another class of drugs which are activators of caspases are the small molecules caspase activators. These are peptides which contain the arginin-glycine-aspartate motif. They are pro-apoptotic and have the ability to induce auto-activation of procaspase 3 directly. They have also been shown to lower the activation threshold of caspase or activate caspase, contributing to an increase in drug sensitivity of cancer cells [101].

\subsubsection{Caspase-based gene therapy}

In addition to caspase-based drug therapy, caspase-based gene therapy has been attempted in several studies. For instance, human caspase-3 gene therapy was used in addition to etoposide treatment in an AH130 liver tumour model and was found to induce extensive apoptosis and reduce tumour volume [102] while gene transfer of constitutively active caspse-3 into $\mathrm{HuH} 7$ human hepatoma cells selectively induced apoptosis in these cells [103]. Also, a recombinant adenovirus carrying immunocaspase 3 has been shown to exert anti-cancer effects in hepatocellular carcinoma in vitro and in vivo [104].

\subsection{Molecules targeting apoptosis in clinical trials}

Recently, many new molecules that target apoptosis enter various stages of clinical trials. A search at http:// www.clinicaltrials.gov (a registry and results database of federally and privately supported clinical trials conducted in the United States and around the world) returns many results. These molecules target various proteins involved in apoptosis. Many are antagonists of IAPs and molecules that target the $\mathrm{Bcl}-2$ family of proteins. Table 3 summarises ongoing or recently completed clinical trials involving molecules that target apoptosis.

\section{Conclusions}

The abundance of literature suggests that defects along apoptotic pathways play a crucial role in carcinogenesis and that many new treatment strategies targeting apoptosis are feasible and may be used in the treatment of various types of cancer. Some of these discoveries are preclinical while others have already entered clinical trials. Many of these new agents or treatment strategies have also been incorporated into combination therapy involving conventional anticancer drugs in several clinical trials, which may help enhance currently available treatment modalities. However, some puzzling and troubling questions such as whether these treatment strategies induce resistance in tumours and whether they will cause normal cells to die in massive numbers still remain unanswered. This is a true concern if lessons were to be learnt from the conventional anticancer drugs, which wipe out both normal cells and tumour cells and cause brutal side effects and tumour resistance. On the other hand, it would be of clinical benefit, if these molecules that target apoptosis are specifically acting on a single pathway or protein. However, most of the molecules that enter clinical trials act on several 
Table 3 Ongoing or recently completed clinical trials involving molecules that target apoptosis

\begin{tabular}{|c|c|c|c|c|}
\hline Molecule name & Sponsor & Target & Condition & $\begin{array}{l}\text { Clinical } \\
\text { stage }\end{array}$ \\
\hline $\begin{array}{l}\text { ABT-263 } \\
\text { (in combination with } \\
\text { erlotinib or irinotecan) }\end{array}$ & Abbott & Bcl-2 family of proteins & Solid tumours & Phase I \\
\hline $\begin{array}{l}\text { ABT-263 } \\
\text { (in combination with } \\
\text { docetaxel) }\end{array}$ & Abbott & Bcl-2 family of proteins & Solid tumours & Phase I \\
\hline $\begin{array}{l}\text { ABT-263 } \\
\text { (in combination with } \\
\text { paclitaxel) }\end{array}$ & Abbott & Bcl-2 family of proteins & Chronic lymphocytic leukaemia & Phase I \\
\hline ABT-263 & Genentech & Bcl-2 family of proteins & Chronic lymphocytic leukaemia & Phase II \\
\hline $\begin{array}{l}\text { AT-101 } \\
\text { (Gossypol) }\end{array}$ & Roswell Park Cancer Institute & Bcl-2 family of proteins & $\begin{array}{l}\text { Lymphocytic leukaemia, } \\
\text { chronic B-cell leukaemia }\end{array}$ & $\begin{array}{l}\text { Phase I } \\
\text { Phase II }\end{array}$ \\
\hline AT-406 & Ascenta Therapeutics & IAPS & $\begin{array}{l}\text { Solid tumours, } \\
\text { lymphoma }\end{array}$ & Phase I \\
\hline AT-406 & Ascenta Therapeutics & IAPS & Acute myelogenous leukaemia & Phase I \\
\hline ENZ-3042 & $\begin{array}{l}\text { Therapeutic Advances in Childhood } \\
\text { Leukaemia Consortium }\end{array}$ & IAPS & $\begin{array}{l}\text { Acute, childhood and T cell } \\
\text { lymphoblastic leukaemia }\end{array}$ & Phase I \\
\hline $\begin{array}{l}\text { GX15-070MS } \\
\text { (Obotoclax) }\end{array}$ & Children's Oncology Group & Bcl-2 family of proteins & $\begin{array}{l}\text { Leukaemia, } \\
\text { lymphoma } \\
\text { unspecified childhood solid } \\
\text { tumour }\end{array}$ & Phase I \\
\hline $\begin{array}{l}\text { GX15-070MS } \\
\text { (Obotoclax) }\end{array}$ & $\begin{array}{l}\text { Arthur G. James Cancer Hospital \& } \\
\text { Richard J. Solove Research Institute }\end{array}$ & Bcl-2 family of proteins & Lymphoma & $\begin{array}{l}\text { Phase I } \\
\text { Phase II }\end{array}$ \\
\hline HGS-1029 & Human Genome Sciences & IAPS & Advanced solid tumours & Phase I \\
\hline HGS-1029 & Human Genome Sciences & IAPs & Advanced solid tumours & Phase I \\
\hline$\overline{L C L-161}$ & Novartis Pharmaceuticals & IAPS & Solid tumours & Phase I \\
\hline RO5458640 & Hoffmann-La Roche & $\begin{array}{l}\text { TNF-like weak inducer of } \\
\text { apoptosis (TWEAK) ligand }\end{array}$ & Advanced solid tumours & Phase I \\
\hline
\end{tabular}

targets and these include many inhibitors of the Bclfamily of proteins and some pan-IAP inhibitors. Hence, evidence-based long-term follow ups on patients receiving these new cancer treatments are needed and ongoing research should focus on those strategies that can selectively induce apoptosis in malignant cells and not the normal ones.

\section{Acknowledgements}

The author would like to acknowledge the International Medical University, Malaysia for funding research that led to the writing of this work (grant number: 231/2011).

\section{Authors' contributions}

RSYW contributed solely to the writing and submission of this work.

\section{Competing interests}

The author declares that there are no competing interests and that this work has not been published or submitted concurrently for publication elsewhere.

Received: 25 August 2011 Accepted: 26 September 2011 Published: 26 September 2011

\section{References}

1. Bauer JH, Hefand SL: New tricks of an old molecule: lifespan regulation by p53. Aging Cell 2006, 5:437-440.
2. Gasco M, Shami S, Crook T: The p53 pathway in breast cancer. Breast Cancer Res 2002, 4:70-76

3. Rodrigues NR, Rowan A, Smith ME, Kerr IB, Bodmer WF, Gannon JV, Lane DP: p53 mutations in colorectal cancers. Proc Natl Acad Sci USA 1990, 87(19):7555-7559.

4. Morton JP, Timpson P, Karim SA, Ridgway RA, Athineos D, Doyle B, Jamieson NB, Oien KA, Lowy AM, Brunton VG, Frame MC, Jeffry Evans TR, Sansom OJ: Mutant p53 drives metastasis and overcomes growth arrest/ senescence in pancreatic cancer. PNAS 2010, 107(1):246-251.

5. Jensen M, Engert A, Weissinger F, Knauf W, Kimby E, Poynton C, Oliff IA, Rummel MJ, Österborg A: Phase I study of a novel pro-apoptotic drug Retodolac in patients with B-cell chronic lymphocytic leukaemia. Invest New Drugs 2008, 26(2):139-149.

6. Baritaki S, Militello L, Malaponte G, Spandidos DA, Salcedo M, Bonavida B: The anti-CD20 mAb LFB-R603 interrupts the dysregulated NF-kB/Snail/ RKIP/PTEN resistance loop in B-NHL cells: role in sensitization to TRAIL apoptosis. Int J Oncol 2011, 38(6):1683-1694.

7. Kerr JF, Harmon BV: Definition and incidence of apoptosis: an historical perspective. In Apoptosis: the molecular basis of cell death. Volume 3. Edited by: Tomei LD, Cope FO. New York: Cold Spring Harbor Laboratory Press; 1991:5-29.

8. Kerr JFR, Wyllie AH, Currie AR: Apoptosis: a basic biological phenomenon with wide-ranging implications in tissue kinetics. Br J Cancer 1972, 26:239-257.

9. Mohan H: Textbook of pathology. 5 edition. New Delhi: Jaypee Brothers Medical Publishers; 2010, 21-60.

10. Merkle CJ: Cellular adaptation, injury, and death. In Pathophysiology: concepts of altered health states.. 8 edition. Edited by: Porth CM, Matfin G. Philadelphia: Wolters Kluwer/Lippincott Williams and Wilkins; 2009:94-111.

11. Hacker G: The morphology of apoptosis. Cell Tissue Res 2000, 301:5-17. 
12. Saraste A, Pulkki K: Morphologic and biochemical hallmarks of apoptosis. Cardiovascular Res 2000, 45:528-537.

13. Ziegler U, Groscurth P: Morphological features of cell death. News Physiol Sci 2004, 19:124-128.

14. Kroemer G, El-Deiry WS, Golstein P, Peter ME, Vaux D, Vandenabeele P Zhivotovsky B, Blagosklonny MV, Malorni W, Knight RA, Piacentini M, Nagata S, Melino G: Classification of cell death: recommendations of the Nomenclature Committee on Cell Death. Cell Death Differ 2005, 12:1463-1467.

15. Manjo G, Joris I: Apoptosis, oncosis, and necrosis. An overview of cell death. Am J Pathol 1995, 146:3-15.

16. Kumar V, Abbas AK, Fausto N, Aster JC: Robins and Cotran: pathologic basis of disease. 8 edition. Philadelphia: Saunders Elsevier; 2010, 25-32.

17. Hengartner MO: Apoptosis: corralling the corpses. Cell 2000, 104:325-328.

18. Vaux D, Silke J: Mammalian mitochondrial IAP-binding proteins. Biochem Biophy Res Commun 2003, 203:449-504.

19. McCarthy NJ, Evan Gl: Methods for detecting and quantifying apoptosis. Curr Top Dev Biol 1998, 36:259-278.

20. Lavrik IN, Golks A, Krammer PH: Caspases: pharmacological manipulation of cell death. J Clin Invest 2005, 115:2665-2672.

21. Galluzi L, Maiuri MC, Vitale I, Zischka H, Castedo M, Zitvogel L, Kroemer G Cell death modalities: classification and pathophysiological implications. Cell Death Differ 2007, 14:1237-1266.

22. O'Brien MA, Kirby R: Apoptosis: a review of pro-apoptotic and antiapoptotic pathways and dysregulation in disease. J Vet Emerg Crit Care 2008, 18(6):572-585.

23. Schneider $\mathrm{P}$, Tschopp J: Apoptosis induced by death receptors. Pharm Acta Helv 2000, 74:281-286.

24. Karp G: Cell and molecular biology: Concepts and experiments. 5 edition. John New Jersey: Wiley and Sons; 2008, 653-657.

25. Danial NN, Korsmeyer SJ: Cell death: critical control points. Cell 2004, 116(2):205-219.

26. Tsujimoto $Y$, Finger $L R$, Yunis J, Nowell PC, Croce $C M$ : Cloning of the chromosome breakpoint of neoplastic B cells with the $t(14 ; 18)$ chromosome translocation. Science 1984, 226:1097-1099.

27. Reed JC: BCl-2 family proteins: regulators of apoptosis and chemoresistance in haematologic malignancies. Semin Haematol 1997, 34:9-19.

28. Kroemer G, Galluzzi L, Brenner C: Mitochondrial membrane permeabilisation in cell death. Physiol Rev 2007, 87(1):99-163.

29. LaCasse EC, Mahoney DJ, Cheung HH, Plenchette S, Baird S, Korneluk RG: IAP-targeted therapies for cancer. Oncogene 2008, 27(48):6252-6275.

30. Ghobrial IM, Witzig TE, Adjei AA: Targeting apoptosis pathways in cancer therapy. CA Cancer I Clin 2005, 55:178-194

31. Szegezdi E, Fitzgerald U, Samali : Caspase-12 and ER stress mediated apoptosis: the story so far. Ann NY Acad Sci 2003, 1010:186-194.

32. Hanahan D, Weinberg RA: The hallmarks of cancer. Cell 2000, 100:57-70.

33. Gross $\mathrm{A}$, McDonnell JM, Korsmeyer SJ: BCL-2 family members and the mitochondria in apoptosis. Genes Dev 1999, 13:1899-1911.

34. Minn AJ, Vélez P, Schendel SL, Liang H, Muchmore SW, Fesik SW, Fill M, Thompson $\mathrm{CB}: \mathrm{BCl}-\mathrm{x}(\mathrm{L})$ forms an ion channel in synthetic lipid membranes. Nature 1997, 385(6614):353-357.

35. Dewson G, Kluc RM: BCl-2 family-regulated apoptosis in health and disease. Cell Health and Cytoskeleton 2010, 2:9-22.

36. Raffo AJ, Perlman H, Chen MW, Day ML, Streitman JS, Buttyan R: Overexpression of bcl-2 protects prostate cancer cells from apoptosis in vitro and confers resistance to androgen depletion in vivo. Cancer Res 1995, 55:4438.

37. Fulda S, Meyer E, Debatin KM: Inhibition of TRAIL-induced apoptosis by BCl-2 overexpression. Oncogene 2000, 21:2283-2294.

38. Minn AJ, Rudin CM, Boise LH, Thompson CB: Expression of Bcl-XL can confer a multidrug resistance phenotype. Blood 1995, 86:1903-1910

39. Miquel C, Borrini F, Grandjouan S, Aupérin A, Viquier J, Velasco V, Duvillard P, Praz F, Sabourin JC: Role of bax mutations in apoptosis in colorectal cancers with microsatellite instability. Am J Clin Pathol 2005 23(4):562-570

40. Goolsby C, Paniagua M, Tallman M, Gartenhaus RB: BCl-2 regulatory pathway is functional in chronic lymphocytic leukaemia. Cytometry B Clin Cytom 2005, 63(1):36-46.
41. Pepper C, Hoy T, Bentley DP: Bcl-2/Bax ratios in chronic lymphocytic leukaemia and their correlation with in vitro apoptosis and clinical resistance. Br J Cancer 1997, 76(7):935-938.

42. Levine AJ, Momand J, Finlay CA: The p53 tumour suppressor gene. Nature 1991, 351(6326):453-456.

43. Bai L, Zhu WG: p53: structure, function and therapeutic applications. Cancer Mol 2006, 2(4):141-153.

44. Oren M, Rotter V: Introduction: p53-the first twenty years. Cell Mol Life Sci 1999, 55:9-11.

45. Lane DP: p53, guardian of the genome. Nature 1992, 358:15-16.

46. Avery-Kiejda KA, Bowden NA, Croft AJ, Scurr LL, Kairupan CF, Ashton KA, Talseth-Palmer BA, Rizos H, Zhang XD, Scott RJ, Hersey P: p53 in human melanoma fails to regulate target genes associated with apoptosis and the cell cycle and may contribute to proliferation. BMC Cancer 2011, 11:203.

47. Slatter TL, Hung N, Campbell H, Rubio C, Mehta R, Renshaw P, Williams G, Wilson M, Engelmann A, Jeffs A, Royds JA, Baird MA, Braithwaite AW: Hyperproliferation, cancer, and inflammation in mice expressing a ه133p53-like isoform. Blood 2011, 117(19):5166-5177.

48. Vikhanskaya F, Lee MK, Mazzoletti M, Broggini M, Sabapathy K: Cancerderived $\mathrm{p} 53$ mutants suppress $\mathrm{p} 53$-target gene expression-potential mechanism for gain of function of mutant p53. Nucl Acids Res 2007, 35(6):2093-2104

49. Vucic $D$, Fairbrother WJ: The inhibitor of apoptosis proteins as therapeutic targets in cancer. Clin Cancer Res 2007, 13(20):5995-6000

50. Wei Y, Fan T, Yu M: Inhibitor of apoptosis proteins and apoptosis. Acto Biochim Biophys Sin 2008, 40(4):278-288

51. Lopes RB, Gangeswaran R, McNeish IA, Wang Y, Lemoine NR: Expression of the IAP protein family is dysregulated in pancreatic cancer cells and is important for resistance to chemotherapy. Int I Cancer 2007, 120(11):2344-2352

52. Vucic D, Stennicke HR, Pisabarro MT, Salvesen GS, Dixit VM: MLIAP, a novel inhibitor of apoptosis that is preferentially expressed in human melanomas. Curr Biol 2000, 10:1359-1366.

53. Ashhab Y, Alian A, Polliack A, Panet A, Ben Yehuda D: Two splicing variants of a new inhibitor of apoptosis gene with different biological properties and tissue distribution pattern. FEBS Lett 2001, 495:56-60.

54. Chen Z, Naito M, Hori S, Mashima T, Yamori T, Tsuruo T: A human IAPfamily gene, apollon, expressed in human brain cancer cells. Biochem Biophys Res Commun 1999, 264:847-854.

55. Small S, Keerthivasan G, Huang Z, Gurbuxani S, Crispino JD: Overexpression of survivin initiates haematologic malignancies in vivo. Leukaemia 2010, 24(11):1920-1926.

56. Krepela E, Dankova P, Moravcikova E, Krepelova A, Prochazka J, Cermak J, Schützner J, Zatloukal P, Benkova K: Increased expression of inhibitor of apoptosis proteins, Survivin and XIAP, in non-small cell lung carcinoma. Int J Oncol 2009, 35(6):1449-1462.

57. Fink SL, Cookson BT: Apoptosis, pyroptosis, and necrosis: mechanistic description of dead and dying eukaryotic cells. Infect Immun 2005, 73(4):1907-1916.

58. Shen XG, Wang $C$, Li Y, Wang L, Zhou B, Xu B, Jiang X, Zhou ZG, Sun XF: Downregulation of caspase- 9 is a frequent event in patients with stage II colorectal cancer and correlates with poor clinical outcome. Colorectal Dis 2010, 12(12):1213-1218.

59. Devarajan E, Sahin AA, Chen JS, Krishnamurthy RR, Aggarwal N, Brun AM, Sapino A, Zhang F, Sharma D, Yang XH, Tora AD, Mehta K: Downregulation of caspase 3 in breast cancer: a possible mechanism for chemoresistance. Oncogene 2002, 21(57):8843-8851.

60. Fong PC, Xue WC, Ngan HYS, Chiu PM, Chan KYK, Tsao GSW, Cheung ANY: Caspase activity is downregulated in choriocarcinoma: a CDNA array differential expression study. J Clin Pathol 2006, 59(2):179-183.

61. Lavrik I, Golks A, Krammer PH: Death receptor signaling. J Cell Sci 2005, 118:265-267.

62. Friesen C, Fulda S, Debatin KM: Deficient activation of the CD95 (APO-1/ Fas) system in drug resistant cells. Leukaemia 1997, 11(11):1833-1841.

63. Fulda S, Los M, Friesen C, Debatin KM: Chemosensitivity of solid tumour cells in vitro is related to activation of the CD95 system. Int J Cancer 1998, 76(1):105-114.

64. Fulda S: Evasion of apoptosis as a cellular stress response in cancer. Int J Cell Biol 2010, 2010:370835. 
65. Reesink-Peters N, Hougardy BM, van den Heuvel FA, Ten Hoor KA Hollema H, Boezen HM, de Vries EG, de Jong S, van der Zee AG: Death receptors and ligands in cervical carcinogenesis: an immunohistochemical study. Gynaecol Oncol 2005, 96(3):705-713.

66. Rai KR, Moore J, Wu J, Novick SC, O'Brien SM: Effect of the addition of oblimersen (Bcl-2 antisense) to fludarabine/cyclophosphamide for replased/refractory chronic lymphocytic leukaemia (CLL) on survival in patients who achieve CR/nPR: Five-year follow-up from a randomized phase III study [abstract]. J Clin Oncol 2008, 26:7008.

67. Abou-Nassar K, Brown JR: Novel agents for the treatment of chronic lymphocytic leukaemia. Clin Adv Haematol Oncol 2010, 8(12):886-895

68. Kang MH, Reynolds CP, BCl-2 inhibitors: Targeting mitochondrial apoptotic pathways in cancer therapy. Clin Cancer Res 2009, 15:1126-1132.

69. Oltersdorf T, Elmore SW, Shoemaker AR, Armstrong RC, Augeri DJ, Belli BA, Bruncko M, Deckwerth TL, Dinges J, Hajduk PJ, Joseph MK, Kitada S, Korsmeyer SJ, Kunzer AR, Letai A, Li C, Mitten MJ, Nettesheim DG, Ng S, Nimmer PM, O'Connor JM, Oleksijew A, Petros AM, Reed JC, Shen W, Tahir SK, Thompson CB, Tomaselli K, Wang B, Wendt MD, Zhang H, Fesik SW, Rosenberg SH: An inhibitor of $\mathrm{BCl}-2$ family proteins induces regression of solid tumours. Nature 2005, 435(7042):677-681.

70. Albershardt TC, Salerni BL, Soderquist RS, Bates DJ, Pletnev AA, Kisselev AF, Eastman A: Multiple BH3 mimetics antagonize antiapoptotic MCL1 protein by inducing the endoplasmic reticulum stress response and upregulating BH3-only protein NOXA. J Biol Chem 2011, 286(28):24882-24895

71. Ocker M, Neureiter D, Lueders M, Zopf S, Ganslmayer M, Hahn EG, Herold C, Schuppan D: Variants of bcl-2 specific siRNA for silencing antiapoptotic bcl-2 in pancreatic cancer. Gut 2005, 54(9):1298-1308.

72. Wu X, Liu X, Sengupta J, Bu Y, Yi F, Wang C, Shi Y, Zhu Y, Jiao Q, Song F: Silencing of Bmi-1 gene by RNA interference enhances sensitivity to doxorubicin in breast cancer cells. Indian J Exp Biol 2011, 49(2):105-112.

73. Roth JA, Nguyen D, Lawrence DD, Kemp BL, Carrasco CH, Ferson DZ, Hong WK, Komaki R, Lee JJ, Nesbitt JC, Pisters KM, Putnam JB, Schea R, Shin DM, Walsh GL, Dolormente MM, Han Cl, Martin FD, Yen N, Xu K Stephens LC, McDonnell TJ, Mukhopadhyay T, Cai D: Retrovirus-mediated wild-type p53 gene transfer to tumuors of patients with lung cancer. Nature Medicine 1996, 2(9):985-991.

74. Chène $P:$ p53 as a drug target in cancer therapy. Expert Opin Ther Patents 2001, 11(6):923-935.

75. Suzuki K, Matusubara $\mathrm{H}$ : Recent advances in $\mathrm{p} 53$ research and cancer treatment. J Biomed Biotech 2011, 2011:978312.

76. John Nemunaitis, Ian Ganly, Fadlo Khuri, James Arseneau, Joseph Kuhn, Todd McCarty, Stephen Landers, Phillip Maples, Larry Rome, Britta Randlev, Tony Reid, Sam Kaye, David Kirn: Selective replication and oncolysis in p53 mutant tumors with ONYX-015, an E1B-55kD gene-deleted adenovirus, in patients with advanced head and neck cancer: A phase II trial. Cancer Res 2000, 60:6359.

77. Boeckler FM, Joerger AC, Jaggi G, Rutherford TJ, Veprintsev DB, Fersht AR: Targeted rescue of a destabilised mutant of p53 by an in silico screened drug. Proc Natl Acad Sci USA 2008, 105(30):10360-10365.

78. Rippin TM, Bykov VJ, Freund SM, Selivanova G, Wiman KG, Fersht A: Characterisation of the p53-rescue drug CP-31398 in vitro and in living cells. Oncogene 2002, 21(14):2119-2129.

79. Shangary S, Wang S: Small-molecule inhibitors of the MDM2-p53 proteinprotein interaction to reactivate p53 function: a novel approach for cancer therapy. Annu Rev Pharmacol Toxicol 2008, 49:223-241.

80. Shangary S, Qin D, McEachern D, Liu M, Miller RS, Qiu S, NikolovskaColeska Z, Ding K, Wang G, Chen J, Bernard D, Zhang J, Lu Y, Gu Q, Shah RB, Pienta KJ, Ling X, Kang S, Guo M, Sun Y, Yang D, Wang Temporal activation of p53 by a specific MDM2 inhibitor is selectively toxic to tumours and leads to complete tumor growth inhibition. Proc Natl Acad Sci USA 2008, 105(10):3933-3938.

81. Lain S, Hollick JJ, Campbell J, Staples OD, Higgins M, Aoubala M, McCarthy A, Appleyard V, Murray KE, Baker L, Thompson A, Mathers J, Holland SJ, Stark MJ, Pass G, Woods J, Lane DP, Westwood NJ: Discovery, in vivo activity, and mechanism of action of a small-molecule p53 activator. Cancer Cell 2008, 13(5):454-463.

82. Kuball J, Schuler M, Antunes Ferreira E, Herr W, Neumann M, ObenauerKutner L, Westreich L, Huber C, Wölfel T, Theobald M: Generating p53specific cytotoxic $T$ lymphocytes by recombinant adenoviral vectorbased vaccination in mice, but not man. Gene Ther 2002, 9(13):833-843.
83. Svane IM, Pedersen AE, Johnsen HE, Nielsen D, Kamby C, Gaarsdal E, Nikolajsen K, Buus S, Claesson MH: Vaccination with p53-peptide-pulsed dendritic cells, of patients with advanced breast cancer: report from a phase I study. Cancer Immunol Immunother 2004, 53(7):633-641.

84. Vermeij R, Leffers N, van der Burg SH, Melief CJ, Daemen T, Nijman HW: Immunological and clinical effects of vaccines targeting p53overexpressing malignancies. J Biomed Biotechnol 2011, $2011: 702146$.

85. Dai $Y$, Lawrence TS, Xu L: Overcoming cancer therapy resistance by targeting inhibitors of apoptosis proteins and nuclear factor-kappa B. Am J Tranl Res 2009, 1(1):1-15.

86. Cao C, Mu Y, Hallahan DE, Lu B: XIAP and Survivin as therapeutic targets for radiation sensitisation in preclinical models of lung cancer. Oncogene 2004, 23:7047-7052.

87. Hu Y, Cherton-Horvat G, Dragowska V, Baird S, Korneluk RG, Durkin JP, Mayer LD, LaCasse EC: Antisense oligonucleotides targeting XIAP induce apoptosis and enhance chemotherapeutic activity against human lung cancer cells in vitro and in vivo. Clin Cancer Res 2003, 9:2826-2836.

88. Ohnishi K, Scuric Z, Schiesti RH, Okamoto N, Takahashi A, Ohnishi T: siRNA targeting NBS1 or XIAP increases radiation sensitivity of human cancer cells independent of TP53 status. Radiat Res 2006, 166:454-462.

89. Yamaguchi $Y$, Shiraki K, Fuke H, Inoue T, Miyashita K, Yamanaka Y, Saitou Y, Sugimoto K, Nakano T: Targeting of X-linked inhibitor of apoptosis protein or Survivin by short interfering RNAs sensitises hepatoma cells to TNF-related apoptosis-inducing ligand- and chemotherapeutic agentinduced cell death. Oncol Rep 2005, 12:1211-1316.

90. Grossman D, McNiff JM, Li F, Altieri DC: Expression and targeting of the apoptosis inhibitor, Survivin, in human melanoma. J Invest Dermatol 1999 113(6):1076-1081.

91. Sharma H, Sen S, Lo ML Mraiggiò, Singh N: Antisense-mediated downregulation of antiapoptotic proteins induces apoptosis and sensitises head and neck squamous cell carcinoma cells to chemotherapy. Cancer Biol Ther 2005, 4:720-727.

92. Du ZX, Zhang HY, Gao DX, Wang HQ, Li YJ, Liu GL: Antisurvivin oligonucleotides inhibit growth and induce apoptosis in human medullary thyroid carcinoma cells. Exp Mol Med 2006, 38:230-240.

93. Kami K, Doi R, Koizumi M, Toyoda E, Mori T, Ito D, Kawaguchi Y, Fujimoto K, Wada M, Miyatake S, Imamura M: Downregulation of Survivin by siRNA diminishes radioresistance of pancreatic cancer cells. Surgery 2005, 138(2):299-305.

94. Liu Q, Dong C, Li L, Sun J, Li C, Li L: Inhibitory effects of the survivin siRNA transfection on human lung adenocarcinoma cells SPCA1 and SH77. Zhongguo Fei Ai Za Zhi 2011, 14(1):18-22.

95. Zhang $X$, Li N, Wang YH, Huang $Y, X u$ NZ, Wu LY: Effects of Survivin siRNA on growth, apoptosis and chemosensitivity of ovarian cancer cells SKOV3/DDP. Zhonghua Zhong Liu Za Zhi 2009, 31(3):174-177.

96. Yang CT, Li JM, Weng HH, Li YC, Chen HC, Chen MF: Adenovirus-mediated transfer of siRNA against Survivin enhances the radiosensitivity of human non-small cell lung cancer cells. Cancer Gene Ther 2010, 17:120-130.

97. Pennati M, Folini M, Zaffaroni N: Targeting Survivin in cancer therapy: fulfilled promises and open questions. Carcinogenesis 2007, 28(6):1133-1139.

98. Sun H, Liu L, Lu J, Qiu S, Yang CY, Yi H, Wang S: Cyclopeptide Smac mimetics as antagonists of IAP proteins. Bioorg Med Chem Lett 2010 20(10):3043-3046.

99. Lu J, McEachern D, Sun H, Bai L, Peng Y, Qiu S, Miller R, Liao J, Yi H, Liu M, Bellail A, Hao C, Sun SY, Ting AT, Wang S: Therapeutic potential and molecular mechanism of a novel, potent, nonpeptide, Smac mimetic SM-164 in combination with TRAIL for cancer treatment. Mol Cancer Ther 2011, 10(5):902-914.

100. Rohn JL, Noteborn MH: The viral death effector Apoptin reveals tumourspecific processes. Apoptosis 2004, 9:315-322.

101. Philchenkov A, Zavelevich M, Kroczak TJ, Los M: Caspases and cancer: mechanisms of inactivation and new treatment modalities. Exp Oncol 2004, 26(2):82-97.

102. Yamabe K, Shimizu S, Ito T, Yoshioka Y, Nomura M, Narita M, Saito I, Kanegae $Y$, Matsuda $\mathrm{H}$ : Cancer gene therapy using a pro-apoptotic gene, caspase-3. Gene Ther 1999, 6(12):1952-1959.

103. Cam L, Boucquey A, Coulomb-L'hermine A, Weber A, Horellou P: Gene transfer of constitutively active caspase- 3 induces apoptosis in a human hepatoma cell line. J Gene Med 2005, 7(1):30-38. 
104. Li X, Fan R, Zou X, Gao L, Jin H, Du R, Xia L, Fan D: Inhibitory effect of recombinant adenovirus carrying immunocaspase-3 on hepatocellular carcinoma. Biochem Bioohys Res Commun 2007, 358(2):489-494.

doi:10.1186/1756-9966-30-87

Cite this article as: Wong: Apoptosis in cancer: from pathogenesis to treatment. Journal of Experimental \& Clinical Cancer Research 2011 30:87.

Submit your next manuscript to BioMed Central and take full advantage of:

- Convenient online submission

- Thorough peer review

- No space constraints or color figure charges

- Immediate publication on acceptance

- Inclusion in PubMed, CAS, Scopus and Google Scholar

- Research which is freely available for redistribution

Submit your manuscript at www.biomedcentral.com/submit
() BioMed Central 